\title{
Effect of ground soybean and starch on intake, digestibility, performance, and methane production of Nellore bulls
}

\author{
L.G. Rossi ${ }^{\mathrm{a}}$, G. Fiorentini ${ }^{\mathrm{a}, *}$, B.R. Vieira ${ }^{\mathrm{a}}$, A. José Neto ${ }^{\mathrm{a}}$, J.D. Messana ${ }^{\mathrm{a}}$, \\ E.B. Malheiros ${ }^{\mathrm{a}}$, T.T. Berchielli ${ }^{\mathrm{a}, \mathrm{b}}$ \\ ${ }^{a}$ Universidade Estadual Paulista (Unesp), Faculdade de Ciências Agrárias e Veterinárias, Via de Acesso Professor Paulo Donato Castellane, km 5 , \\ Rural, Jaboticabal, Sao Paulo CEP 14884-900, Brazil \\ ${ }^{\mathrm{b}}$ INCT/CA-UFV-Department of Animal Science, Av. Peter Henry Rolfs s/n, Campus Universitário, Viçosa, Minas Gerais CEP $36570-000$, Brazil
}

\section{A R T I C L E I N F O}

\section{Keywords:}

Bos indicus

Carcass

Corn

Greenhouse gases

Soybean

Soybean hulls

\begin{abstract}
A B S T R A C T
It was hypothesized that replacement of corn with soybean hulls as the energy source, combined with ground soybean as the lipid source, would reduce methane emissions from feedlot animals without affecting their performance. This study aimed to evaluate the effects of including ground soybean combined with either a high or a low level of starch on intake, digestibility, performance, and methane emission of young Nellore bulls $(n=28$, initial weight $=395 \pm$ $32 \mathrm{~kg}$ ) in the feedlot during the finishing phase. Diet treatments consisted of high (HS; approx. $250 \mathrm{~g} / \mathrm{kg}$ ) or low (LS; approx. $110 \mathrm{~g} / \mathrm{kg}$ ) starch levels, with (WSB) or without (NSB) soybean. Ground soybean was added as a lipid source to diets HS-WSB, LS-WSB, HS-NSB, and LS-NSB, representing 58.7, 64.6, 24.8, and $31.4 \mathrm{~g} / \mathrm{kg}$ ether extract in the total dry matter, respectively. Animals were distributed in a completely randomized design, in a $2 \times 2$ factorial arrangement. After 119 days, the animals were slaughtered. Animals fed soybean demonstrated an average reduction of $11 \%$ in their intakes of dry matter, organic matter, and crude protein $(P=0.01)$. There was a significant effect of the association between starch and soybean on neutral detergent fiber intake $(P=0.01)$. Diets containing soybean affected the digestibility of the animals, reducing the apparent digestibility of dry matter by $3 \%(\mathrm{P}=0.02)$ and the digestibility of organic matter by $2.8 \%(P=0.03)$. A significant interaction was detected between starch and soybean on the apparent digestibility of ether extract $(\mathrm{P}=0.02)$ and neutral detergent fiber $(P=0.04)$; the lowest values for ether extract $(750 \mathrm{~g} / \mathrm{kg})$ and neutral detergent fiber $(432 \mathrm{~g} / \mathrm{kg})$ were obtained with HS-WSB. The animals that received WSB had their feed efficiency increased by $17 \%(\mathrm{P}=0.01)$. The enteric $\mathrm{CH}_{4}$ emissions of the animals fed WSB reduced significantly ( $\mathrm{P}=0.01$ ), with $28 \%$ decrease in $\mathrm{g} \mathrm{CH}_{4} / \mathrm{d}$ and $\mathrm{g} \mathrm{CH}_{4} / \mathrm{y}, 16 \%$ decrease in $\mathrm{g} \mathrm{CH}_{4}$ per $\mathrm{kg}$ of dry matter intake, and $23 \%$ decrease in $\mathrm{CH}_{4}$ losses per percent of gross energy intake. The inclusion of approximately $250 \mathrm{~g} / \mathrm{kg}$ of soybean in the diet of young Nellore bulls in the feedlot provides an increase in their feed efficiency and reduces their enteric methane emission, regardless of the level of starch in the concentrate.
\end{abstract}

\footnotetext{
Abbreviations: aNDF, neutral detergent fiber assayed with a heat stable amylase and expressed inclusive of residual ash; $\mathrm{BFT}$, backfat thickness; $\mathrm{CG}$, carcass gain; $\mathrm{CH}_{4}$, methane; CP, crude protein; DM, dry matter; DP ref, dressing percentage of the reference animals; EE, ether extract; GE, Gross energy; GHG, greenhouse gas; HCW, hot carcass weight; iNDF, indigestible neutral detergent fiber; IW, initial weight; LEA, loin-eye area; MM, mineral matter; $\mathrm{NFC}$, Non-fiber carbohydrates; $\mathrm{N}-\mathrm{NH}_{3}$, ammoniacal nitrogen; NSB, without soybean; $\mathrm{S}$, starch; $\mathrm{SB}$, soybean; $\mathrm{SF}_{6}$, sulfur hexafluoride; WSB, with soybean

* Corresponding author at: Departamento de Zootecnia, Faculdade de Ciências Agrárias e Veterinárias de Jaboticabal, Universidade Estadual Paulista "Júlio de Mesquita Filho", Rod. Professor Paulo Donato Castellane, km 5, Rural, Jaboticabal, São Paulo CEP 14884-900, Brazil.

E-mail address: fiorentini.giovani@gmail.com (G. Fiorentini).
} 


\section{Introduction}

The current increase in the production of greenhouse gases (GHGs) and their contribution to climate change is a major worldwide concern (Martin et al., 2010). Methane $\left(\mathrm{CH}_{4}\right)$ released by ruminants is the main GHG at the farm level (Veysset et al., 2010) and constitutes an energy loss for the animal ranging from 2 to $12 \%$ of its gross energy intake (Johnson and Johnson, 1995). Therefore, lowering enteric methane production should reduce such inefficiency as well as the environmental impact of ruminant production.

One of the strategies for reducing methane emissions is the inclusion of dietary lipids (Fiorentini et al., 2014). The addition of lipids to ruminant diets increases energy efficiency and reduces methanogenesis simultaneously. The addition of soybeans decreases ruminal protozoa (Fiorentini et al., 2013); protozoa being important producers of $\mathrm{H}_{2}$ in the rumen, the decreased amount of protozoa reduces the availability of substrate for the metabolism of methanogens, thereby reducing $\mathrm{CH}_{4}$ production (Martin et al., 2010). Of the various lipid sources available for ruminant nutrition in Brazil, soybean is valued for its wide availability, low cost, and high nutritive content (Barletta et al., 2012). Brazil is currently the world's largest soybean producer (USDA, 2014).

Another strategy that can be used in methane mitigation is the addition of readily fermentable starch grains to the diet, which promotes propionate production and may consequently reduce the level of methane produced (Moss et al., 2000). However, increasing the concentrations of starch in the diet may reduce the ruminal digestibility of neutral detergent fiber (NDF); this reduction can be partially explained by negative effects of higher starch intake on the ruminal bacterial populations (Ferraretto and Shaver, 2012). Soybean hulls provide an alternative energy source that represents a highly digestible fibrous ingredient (Van Soest, 1994) with minimal effects on fiber degradation (Firkins, 1997; Bach et al., 1999).

Few studies (Neto et al., 2015) to date have investigated the combined effect of starch and lipids on animal performance and methane emission. We hypothesized that replacing corn with soybean hulls as an energy source, combined with ground soybean as a lipid source, may reduce methane emissions without affecting the performance or carcass characteristics of feedlot beef cattle. The aim of this study was, thus, to evaluate the effect of including soybean combined with either a high or a low level of starch in the finishing of feedlot young Nellore bulls on their intake and digestibility, weight gain, carcass characteristics, and methane production.

\section{Materials and methods}

The procedures adopted in this experiment were approved by the Ethics, Bioethics, and Animal Welfare Committee (Comissão de Ética e Bem Estar Animal) of the Faculty of Agriculture and Veterinary Sciences - São Paulo State University (UNESP) protocol no. 021119/11.

The experiment was conducted in the facilities of the experimental feedlot at the Digestibility Unit of the Department of Animal Science at the Faculty of Agriculture and Veterinary Sciences at São Paulo State University, in Jaboticabal, SP, Brazil.

\subsection{Experimental animals}

Thirty-six young Nellore bulls with an average initial body weight of $395 \pm 32 \mathrm{~kg}$ and an average initial age of $20 \pm 3$ months were used in the experiment. Of these, 8 were slaughtered to be used as reference for estimation of initial carcass weight gain, daily carcass gain, and final carcass gain relative to average daily weight gain. The remaining 28 animals were weighed, marked for identity, treated against ecto- and endo-parasites, and then acclimatized to the experimental diets (adopting the same treatments used on pasture) and feedlot facilities for 21 days.

Animals were kept in individual $21 \mathrm{~m}^{2}(7 \times 3 \mathrm{~m})$ stalls containing a wooden trough and a drinker, and were allocated to experimental treatments in a completely randomized design under a $2 \times 2$ factorial arrangement (high or low starch; with or without ground soybean), totaling 4 treatments with 7 replicates per treatment. Total weight gain and average daily gain were determined at the beginning and end of the feedlot period, after a solid-feed deprivation period of $12 \mathrm{~h}$. Animals were weighed at 30-day intervals to monitor variations in performance. After 140 days of feeding (adaptation + experimental period), the animals, with an average body weight of $590 \pm 34 \mathrm{~kg}$, were slaughtered in a commercial beef plant.

\subsection{Diets}

Diets were supplied once daily at 08:00 h. The diets were formulated to be isonitrogenous, and to provide a dry matter intake of $22.0 \mathrm{~g} / \mathrm{kg}$ of body weight and an average gain of $1.30 \mathrm{~kg} /$ day as per Valadares Filho et al. (2010). Feed supply was adjusted daily based on the previous day's intake, maintaining orts at approximately $100 \mathrm{~g} / \mathrm{kg}$ of the total provided, characterizing ad libitum intake.

Diet treatments consisted of high (HS; approx. $250 \mathrm{~g} / \mathrm{kg}$ ) or low (LS; approx. $110 \mathrm{~g} / \mathrm{kg}$ ) starch levels, with (WSB; approx. $62 \mathrm{~g} / \mathrm{kg}$ ether extract) or without (NSB; approx. $28 \mathrm{~g} / \mathrm{kg}$ ether extract) ground soybean. In HS, the main ingredient was corn, whereas soybean hulls were the main ingredient in LS; ground soybean was added as a lipid source. The roughage used was corn silage, and the roughage:concentrate ratio of the experimental diets was 400:600 g/kg (Table 1). All diets contained $100 \mathrm{~g}$ crude glycerin per kg of dry matter, replacing the corn or soybean hulls. Glycerin is a by-product from the biodiesel industry that can be used in ruminant diets without compromising intake or performance (Parsons et al., 2009; Drouillard, 2012). 
Table 1

Proportion of ingredients and chemical composition of the experimental diets and corn silage ( $\mathrm{g} / \mathrm{kg}$ on a DM basis).

\begin{tabular}{|c|c|c|c|c|c|}
\hline & \multicolumn{2}{|c|}{ High Starch } & \multicolumn{2}{|c|}{ Low Starch } & \multirow[t]{2}{*}{ Corn Silage } \\
\hline & $\mathrm{WSB}^{\mathrm{a}}$ & $\mathrm{NSB}^{\mathrm{b}}$ & $\mathrm{WSB}^{\mathrm{a}}$ & $\mathrm{NSB}^{\mathrm{b}}$ & \\
\hline \multicolumn{6}{|l|}{ Ingredient proportions } \\
\hline Corn Silage & 400 & 400 & 400 & 400 & - \\
\hline Corn & 240 & 303.4 & 0.00 & 0.00 & - \\
\hline Soybean meal & 0.00 & 176 & 0.00 & 157 & - \\
\hline Soybean hulls & 0.00 & 0.00 & 206.8 & 238.6 & - \\
\hline Ground soybean & 239 & 0.00 & 273 & 0.00 & - \\
\hline Crude glycerin & 100 & 100 & 100 & 100 & - \\
\hline Commercial premix ${ }^{c}$ & 20.5 & 20.5 & 20.5 & 20.5 & - \\
\hline \multicolumn{6}{|l|}{ Chemical composition } \\
\hline Dry matter & 601 & 603 & 589 & 586 & 269 \\
\hline Organic matter & 957 & 959 & 947 & 947 & - \\
\hline $\operatorname{Starch}^{\mathrm{d}}$ & 240 & 259 & 121 & 97.8 & 179 \\
\hline Crude protein & 140 & 147 & 156 & 152 & 84.5 \\
\hline Ether extract & 58.7 & 24.8 & 64.6 & 31.4 & 24.7 \\
\hline Non-fiber carbohydrates & 485 & 512 & 386 & 403 & - \\
\hline Total carbohydrates & 758 & 781 & 726 & 763 & - \\
\hline aNDF & 177 & 172 & 244 & 265 & 42.8 \\
\hline Lignin & 84.1 & 78.4 & 87.5 & 83.3 & - \\
\hline Gross energy, MJ/kg DM & 17.4 & 16.7 & 17.5 & 16.5 & - \\
\hline
\end{tabular}

${ }^{\mathrm{a}}$ WSB $=$ With ground soybean.

${ }^{\mathrm{b}} \mathrm{NSB}=$ No ground soybean.

c $120 \mathrm{~g}$ calcium, $30 \mathrm{~g}$ phosphorus, $25 \mathrm{~g}$ sulfur, $80 \mathrm{~g}$ sodium, $330 \mathrm{mg}$ copper, $950 \mathrm{mg}$ manganese, $1220 \mathrm{mg}$ zinc, $24 \mathrm{mg}$ iodine, $20 \mathrm{mg}$ cobalt, $6 \mathrm{mg}$ selenium, and $300 \mathrm{mg}$ fluorine.

${ }^{\mathrm{d}}$ Calculated based on ingredient values from Valadares Filho et al. (2010).

\subsection{Sampling and characterization of diet}

Samples of concentrates, roughage, and orts were collected at 30-day intervals and stored in a freezer. Subsequently, composite samples were made and dried in a forced-air oven at $55{ }^{\circ} \mathrm{C}$ for $72 \mathrm{~h}$ and then ground in a Wiley mill to pass through a 1 -mm sieve. Dry matter (method 934.01; AOAC, 1990), mineral matter (MM; method 942.05; AOAC, 1990), ether extract (EE; method 954.02; AOAC, 1990), and lignin (method 973.18; AOAC, 1990) contents were quantified. Neutral detergent fiber (aNDF) was determined using $\alpha$ amylase and without the addition of sodium sulfite by following the procedure of Van Soest et al. (1991), and adapted for the Ankom200 Fiber Analyzer (Ankom Technology, Fairport, NY).

Nitrogen concentration was determined in each sample by rapid combustion $\left(850{ }^{\circ} \mathrm{C}\right)$, conversion of all N-combustion products to $\mathrm{N}_{2}$, and subsequent measurement using a thermoconductivity cell (Leco model FP-528; LECO Corporation, Michigan, USA). Crude protein (CP) was calculated by multiplying the percentage of $\mathrm{N}$ in the sample by 6.25. Gross energy (GE) content was determined using an adiabatic bomb calorimeter (SRPA Instrument Company 6300, Moline, IL, USA). The concentration of starch in concentrates and silage was determined according to Knudsen et al. (1987).

Samples of the corn silage were collected during each experimental trial for estimation of $\mathrm{pH}$, ammoniacal nitrogen $\left(\mathrm{N}-\mathrm{NH}_{3}\right)$, and chemical analyses. An aqueous extract was prepared (Kung et al., 1984) for $\mathrm{pH}$ and $\mathrm{N}-\mathrm{NH}_{3}$ determination; non-fiber carbohydrates (NFC) and total carbohydrates from the diets and orts were calculated according to the methodology of Cornell University, described by Sniffen et al. (1992).

\subsection{Digestibility trial}

Digestibility trials were performed in the middle third of each experimental period (days 20 and 21); the upper layer of feces was collected on two consecutive days from the floor of the stalls immediately after defecation by each animal. On the first day, the collection was performed in the morning, and on the second day, in the afternoon. After being identified, feces were pre-dried in a forced-air oven at $55^{\circ} \mathrm{C}$ for approximately $72 \mathrm{~h}$ and ground through a 1-mm sieve mill. A composite sample based on the air-dry weight was made from the three samples of ground feces.

The fecal output of dry matter was estimated by the internal marker technique (Cochran et al., 1986), using the indigestible neutral detergent fiber (iNDF) marker. iNDF was obtained by the in situ method for $240 \mathrm{~h}$ (Casali et al., 2008) with subsequent extraction of the neutral detergent fiber according to Van Soest et al. (1991).

\subsection{Quantification of enteric methane}

Methane $\left(\mathrm{CH}_{4}\right)$ emissions were measured by the sulfur hexafluoride $\left(\mathrm{SF}_{6}\right)$ tracer gas technique (Johnson and Johnson, 1994), for which each animal was sampled daily for five consecutive days at the end of the final feeding period, so as not to compromise intake 
and performance. All animals were fitted with gas-collection halters 10 days before $\mathrm{CH}_{4}$ sampling to allow the animals to adapt, and to facilitate sampling. Brass permeation tubes filled with $\mathrm{SF}_{6}$ with known release rates $\left(2.23 \pm 0.5 \mathrm{mg} \mathrm{SF}_{6} / \mathrm{d}\right.$, mean $\left.\pm \mathrm{SD}\right)$ were administered orally to all the animals $72 \mathrm{~h}$ before $\mathrm{CH}_{4}$ sampling to allow the marker gas to equilibrate in the rumen. Gas release rates from permeation tubes were determined prior to their placement into the rumen. The permeation tubes were maintained in a water bath at $39^{\circ} \mathrm{C}$ and weighed in the laboratory for 7 weeks.

Animals were fitted with gas-collection halters connected to pre-evacuated polyvinyl chloride canisters designed to fill halfway over $24 \mathrm{~h}$. Sampling began prior to feeding at 06:00 h daily, whereby each animal was removed from the paddock individually and conducted to the stockyard to facilitate sampling.

Collection canisters were positioned above the neck of each animal to reduce the risk of equipment damage and were connected to the halter by airline flexible-coil tubing. Canister pressure was measured after $24 \mathrm{~h}$ of collection and the halter replaced if the final pressure was beyond the expected range (from $-12,000$ [initial pressure] to -6000 [final pressure] PSI); higher pressure indicated probable blockage of the halter, whereas lower pressure indicated a probable leak in the system. In both situations, a new halter was placed on the animal to achieve an average absorption rate within the stipulated range; filling halfway over $24 \mathrm{~h}$.

Pressure readings were recorded and canisters were pressurized using pure $\mathrm{N}_{2}$. Averages of two ambient air samples in the feedlot were collected daily to determine the background concentrations of $\mathrm{CH}_{4}$ and $\mathrm{SF}_{6}$. The net output in exhaled air was calculated by correction against background values. The $\mathrm{CH}_{4}$ emission rate was calculated as follows (Westberg et al., 1998): $\mathrm{QCH}_{4}=\mathrm{QSF}_{6} \times\left(\left[\mathrm{CH}_{4}\right]_{\mathrm{y}}-\left[\mathrm{CH}_{4}\right]_{\mathrm{B}}\right) /\left[\mathrm{SF}_{6}\right]$, in which $\mathrm{QCH}_{4}$ is the methane emission rate in $\mathrm{g} / \mathrm{d}$; QSF 6 is the known release rate of $\mathrm{SF}_{6}$ from the permeation tube; $\left[\mathrm{CH}_{4}\right]_{\mathrm{y}}$ and $\left[\mathrm{SF}_{6}\right]$ are the concentrations of respective gases in the canister, and $\left[\mathrm{CH}_{4}\right]_{\mathrm{B}}$ is the background concentration of methane in ambient air. From these data, $\mathrm{CH}_{4}$ emissions were calculated per day, per year, and as a function of average daily gain, carcass gain, dry matter intake, aNDF intake, and gross energy intake.

\subsection{Slaughter and evaluation of carcass}

Slaughter was performed in a commercial abattoir under federal inspection, according to the animal welfare norms. The carcass of each animal was divided into two half-carcasses and weighed to determine the hot carcass weight (HCW). Carcasses were then chilled in a cold room at $0{ }^{\circ} \mathrm{C}$ for $24 \mathrm{~h}$. After weighing, the left half-carcass was sectioned between the 12th and 13th ribs, and the longissimus muscle was used for measurements of backfat thickness (BFT) and loin-eye area (LEA). A digital caliper was used to determine BFT, and a proper square grid was used for LEA, with measurements in square centimeters $\left(\mathrm{cm}^{2}\right)$.

Hot carcass yield was calculated as the ratio between hot carcass weight and body weight of each fasted animal in percentage. The daily carcass gain (CG) was obtained based on the reference animals:

$\mathrm{CG}=[\mathrm{HCW}-(\mathrm{IW} \times \mathrm{DP}$ ref $)] /$ days;

where HCW $=$ hot carcass weight of experimental animals, IW $=$ initial weight of experimental animals, and DP ref $=$ dressing percentage of the reference animals.

\subsection{Statistical analyses}

The experimental design was completely randomized in a $2 \times 2$ factorial arrangement ( 2 levels of each factor), and data were analyzed using the MIXED procedure of SAS software (SAS Inst. Inc., Cary, NC). The model included the fixed effects starch and lipid source with interaction:

$\mathrm{Y}_{i j k}=\mu+\mathrm{S}_{i}+\mathrm{O}_{k}+\left[\mathrm{S}_{i} \times \mathrm{O}_{k}\right]+\mathrm{e}_{i j k}$

where $Y_{i j k}=$ observation of animal $j$ subjected to starch $i$ at soybean inclusion $k, \mu=$ overall mean, $\mathrm{S}_{i}=$ effect of starch $i=1$ and 2 , $\mathrm{O}_{k}=$ effect of soybean inclusion $k=1$ and $2, \mathrm{~S}_{i} \times \mathrm{O}_{k}=$ interaction between starch $i$ and soybean inclusion $k$, and $e_{i j k}=$ residual experimental error.

Homogeneity of the data was verified using the UNIVARIATE procedure of SAS. Studentized residuals were plotted against the predicted values using the plot procedure to analyze data for outliers. Results were subjected to analysis of variance with means compared by Tukey's test at $5 \%$ level of significance.

\section{Results}

There was no significant effect of the interaction between the factors (soybean and starch) on the variables shown in Table 2 . Animals fed WSB demonstrated an 11\% average decrease in intake of dry matter, organic matter, crude protein, and total digestible nutrients $(P=0.01)$. Inclusion of HS in the diet increased intake rates of dry matter $(P=0.04)$, organic matter $(P=0.02)$, and total digestible nutrients $(P=0.03)$ by $7 \%$ and GE intake $(P=0.02)$ by $10 \%$, as compared to LS diets (Table 2).

A significant effect of interaction $(P=0.01)$ between starch and soybean on aNDF intake was detected, with the lowest value in the animals fed HS-WSB (Table 3). The WSB diets affected the digestibility of animals, reducing the apparent digestibility of dry matter by $3 \%$ and organic matter by $2.8 \%$, as compared to that in animals fed NSB diets. The apparent digestibility of protein was not affected by any diet $(P>0.05)$.

Inclusion of HS or LS did not affect $(P>0.05)$ the apparent digestibility of nutrients in any treatment (Table 2$)$. A significant 
Table 2

Effect of diets containing high and low starch, with or without soybean (soy ground or no soy ground) on intake and digestibility of Nellore bulls finished in feedlot.

\begin{tabular}{|c|c|c|c|c|c|c|c|c|}
\hline & \multicolumn{2}{|c|}{ Soybean } & \multicolumn{2}{|l|}{ Starch } & \multirow[b]{2}{*}{ SEM } & \multicolumn{3}{|c|}{$P$-value } \\
\hline & With & No & High & Low & & $\mathrm{SB}^{1}$ & $S^{2}$ & $\mathrm{SB} \times \mathrm{S}$ \\
\hline \multicolumn{9}{|l|}{ Intake, $\mathrm{g} / \mathrm{kg}$ of $\mathrm{BW}$} \\
\hline Dry matter & $16.4^{\mathrm{b}}$ & $18.4^{\mathrm{a}}$ & $18.2^{\mathrm{a}}$ & $16.6^{\mathrm{b}}$ & 0.12 & 0.01 & 0.01 & 0.69 \\
\hline \multicolumn{9}{|l|}{ Intake, $\mathrm{kg} / \mathrm{d}$} \\
\hline Dry matter & $8.31^{\mathrm{b}}$ & $9.55^{\mathrm{a}}$ & $9.26^{\mathrm{a}}$ & $8.60^{\mathrm{b}}$ & 0.82 & 0.01 & 0.04 & 0.49 \\
\hline Organic matter & $7.92^{\mathrm{b}}$ & $9.07^{\mathrm{a}}$ & $8.84^{\mathrm{a}}$ & $8.14^{\mathrm{b}}$ & 0.78 & 0.01 & 0.02 & 0.46 \\
\hline Crude protein & $1.23^{\mathrm{b}}$ & $1.45^{\mathrm{a}}$ & 1.35 & 1.32 & 0.11 & 0.01 & 0.47 & 0.66 \\
\hline Ether extract & $0.52^{\mathrm{a}}$ & $0.27^{\mathrm{b}}$ & 0.38 & 0.41 & 0.04 & 0.01 & 0.10 & 0.10 \\
\hline Gross energy, MJ/d & 145 & 153 & $157^{\mathrm{a}}$ & $141^{b}$ & 6.54 & 0.23 & 0.02 & 0.75 \\
\hline \multicolumn{9}{|l|}{ Digestibility, g/kg DM } \\
\hline Dry matter & $689^{\mathrm{b}}$ & $712^{\mathrm{a}}$ & 702 & 700 & 2.38 & 0.02 & 0.74 & 0.44 \\
\hline Organic matter & $704^{b}$ & $725^{\mathrm{a}}$ & 713 & 714 & 2.40 & 0.03 & 0.93 & 0.51 \\
\hline Crude protein & 634 & 641 & 629 & 647 & 2.66 & 0.51 & 0.06 & 0.09 \\
\hline
\end{tabular}

${ }^{1} \mathrm{SB}=$ Soybean; ${ }^{2} \mathrm{~S}=$ Starch.

${ }^{\mathrm{a}-\mathrm{b}}$ Homogeneous subsets within rows as determined by Tukey HSD at the $5 \%$ level.

interaction was apparent between starch and soybean for the apparent digestibility of ether extract $(P=0.02)$ and aNDF $(P=0.04$; Table 3). The feed efficiency of animals consuming WSB increased $(P=0.01)$ by $17 \%$; however, no effect of any dietary treatment was observed on average daily gain, carcass yield, carcass gain, loin-eye area, and backfat thickness $(P>0.05$; Table 4$)$.

The enteric $\mathrm{CH}_{4}$ emissions of animals fed WSB reduced significantly, with a $28 \%$ decrease in daily and yearly $\mathrm{CH}_{4}$ emissions $(P=0.01), 27 \%$ decrease in $\mathrm{g} \mathrm{CH}_{4}$ per kg of average daily gain $(P=0.01), 22 \%$ decrease in $\mathrm{g} \mathrm{CH}_{4}$ per kg of carcass gain $(P=0.01)$, $16 \%$ decrease in $\mathrm{g} \mathrm{CH}_{4}$ per $\mathrm{kg}$ of dry matter intake $(P=0.01), 14 \%$ decrease in $\mathrm{g} \mathrm{CH}_{4}$ per $\mathrm{kg}$ of aNDF intake $(P=0.03)$, and $23 \%$ decrease in $\mathrm{CH}_{4}$ losses per percent of gross energy intake $(P=0.01)$. Dietary starch content $(\mathrm{HS}$ or LS) did not affect $(P>0.05)$ enteric $\mathrm{CH}_{4}$ production (Table 5).

\section{Discussion}

Addition of ground soybean to the diets of young Nellore bulls was associated with decreases in the intake and digestibility of nutrients and $\mathrm{CH}_{4}$ emissions during the present study, regardless of the level of dietary starch. The addition of ground soybean as a lipid source was shown to have a significant effect on the intake of DM, OM, CP, and aNDF. This is consistent with previous experiments in which a decrease in DM intake was observed in feedlot cattle fed diets containing soybean (Bassi et al., 2012; Fiorentini et al., 2014).

Animals fed WSB, during the present study, had a higher EE intake (62 g/kg DM) than those fed NSB diets (28 g/kg DM). Diets containing $70 \mathrm{~g}$ or more of EE/ kg DM may cause depression of feeding and may be toxic to rumen microorganisms, because the excess lipid adheres to food particles, creating a physical barrier that impedes the activity of microorganisms and microbial enzymes, especially when a large proportion of unsaturated fatty acids is contained in the EE (Palmquist and Jenkins, 1980; Sullivan et al., 2004). Higher EE intake of WSB fed animals might have also been caused by increased serum concentrations of unsaturated fatty

Table 3

Effect of diets containing high and low starch, with or without soybean (soy ground or no soy ground) on digestibility of EE, aNDF and intake of aNDF of Nellore bulls finished in feedlot.

\begin{tabular}{|c|c|c|c|c|c|c|c|}
\hline & & \multicolumn{2}{|l|}{ Starch } & \multirow[b]{2}{*}{ SEM } & \multicolumn{3}{|c|}{$P$-value } \\
\hline & & High & Low & & $\mathrm{SB}^{1}$ & $S^{2}$ & $\mathrm{SB} \times \mathrm{S}$ \\
\hline \multicolumn{8}{|l|}{ Intake, $\mathrm{kg} / \mathrm{d}$} \\
\hline \multirow[t]{2}{*}{ aNDF } & With SB & $2.32^{\mathrm{A}, \mathrm{b}}$ & $2.63^{\mathrm{B}, \mathrm{a}}$ & 0.25 & 0.01 & 0.01 & 0.01 \\
\hline & No SB & $2.52^{\mathrm{A}, \mathrm{b}}$ & $3.32^{\mathrm{A}, \mathrm{a}}$ & & & & \\
\hline \multicolumn{8}{|c|}{ Digestibility, g/kg DM } \\
\hline \multirow[t]{2}{*}{ Ether extract } & With SB & $751^{\mathrm{A}, \mathrm{b}}$ & $876^{\mathrm{A}, \mathrm{a}}$ & 3.85 & 0.07 & 0.01 & 0.02 \\
\hline & No SB & $758^{\mathrm{A}, \mathrm{b}}$ & $812^{\mathrm{B}, \mathrm{a}}$ & & & & \\
\hline \multirow[t]{2}{*}{ aNDF } & With SB & $431^{\mathrm{B}, \mathrm{b}}$ & $538^{\mathrm{A}, \mathrm{a}}$ & 3.12 & 0.01 & 0.01 & 0.04 \\
\hline & No SB & $496^{\mathrm{A}, \mathrm{b}}$ & $553^{\mathrm{A}, \mathrm{a}}$ & & & & \\
\hline
\end{tabular}

${ }^{1} \mathrm{SB}=$ Soybean; ${ }^{2} \mathrm{~S}=$ Starch.

${ }^{\mathrm{a}-\mathrm{b}}$ Homogeneous subsets within rows as determined by Tukey HSD at the $5 \%$ level.

${ }^{\mathrm{A}-\mathrm{B}}$ Homogeneous subsets within columns as determined by Tukey HSD at the $5 \%$ level. 
Table 4

Effect of diets containing high and low starch, with or without soybean (soy ground or no soy groun) on initial and final body weight, average daily gain (ADG), feed efficiency, carcass yield, carcass gain, loin-eye area and backfat thickness of Nellore bulls finished in feedlot.

\begin{tabular}{|c|c|c|c|c|c|c|c|c|}
\hline & \multicolumn{2}{|c|}{ Soybean } & \multicolumn{2}{|l|}{ Starch } & \multirow[b]{2}{*}{ SEM } & \multicolumn{3}{|c|}{$P$-value } \\
\hline & With & No & High & Low & & $\mathrm{SB}^{1}$ & $S^{2}$ & $\mathrm{SB} \times \mathrm{S}$ \\
\hline Initial body weight, $\mathrm{kg}$ & 425 & 432 & 426 & 431 & 37.1 & 0.63 & 0.70 & 0.93 \\
\hline Final body weight, kg & 588 & 592 & 593 & 587 & 55.3 & 0.88 & 0.75 & 0.99 \\
\hline Average daily gain, $\mathrm{kg} / \mathrm{d}$ & 1.37 & 1.39 & 1.41 & 1.36 & 0.18 & 0.81 & 0.46 & 0.44 \\
\hline Feed efficiency ${ }^{3}$ & $0.17^{\mathrm{a}}$ & $0.14^{\mathrm{b}}$ & 0.15 & 0.16 & 0.01 & 0.01 & 0.56 & 0.70 \\
\hline Carcass yield $^{4}$ & 58.3 & 58.8 & 58.8 & 58.3 & 1.52 & 0.38 & 0.41 & 0.65 \\
\hline Carcass gain, kg/d & 1.00 & 1.08 & 1.08 & 1.00 & 0.11 & 0.07 & 0.07 & 0.29 \\
\hline Loin-eye area, $\mathrm{cm}^{2}$ & 84.9 & 86.3 & 89.5 & 81.7 & 11.6 & 0.74 & 0.08 & 0.27 \\
\hline Loin-eye area ${ }^{5}$ & 25.0 & 24.8 & 25.5 & 24.2 & 2.61 & 0.82 & 0.20 & 0.22 \\
\hline Backfat thickness, mm & 6.70 & 6.22 & 6.04 & 6.88 & 1.85 & 0.50 & 0.24 & 0.51 \\
\hline
\end{tabular}

${ }^{1} \mathrm{SB}=$ Soybean; ${ }^{2} \mathrm{~S}=$ Starch; ${ }^{3} \mathrm{~kg}$ ADG $/ \mathrm{kg}$ DM intake; ${ }^{4} \mathrm{~kg} / 100 \mathrm{~kg}$ of carcass; ${ }^{5} \mathrm{~cm}^{2} / 100 \mathrm{~kg}$ of carcass.

${ }^{\mathrm{a}-\mathrm{bb}}$ Homogeneous subsets within rows as determined by Tukey HSD at the $5 \%$ level.

acids, which activate the receptors in the satiety center of the hypothalamus (Allen, 2000; Obici et al., 2002). Therefore, it can be inferred that the differences in the intake of DM and nutrients observed during the present study were a result of the differential lipid intake of the animals.

The association between starch (high and low) and a lipid source may not influence DM intake, and an alteration in this component depends on the level of lipid inclusion (Neto et al., 2015). This reinforces the idea that the effect of lipid addition on intake is highly variable, depending mainly on the source and amount utilized, the category of animals under study, and the form of supply, among other characteristics.

The significant decrease in aNDF intake observed in animals fed HS-WSB diets during the present study was due to the lower aNDF content of this diet compared with the LS diet. Differences in the aNDF content of diets were due to the high percentage of aNDF in the soybean hulls. Dietary soybean addition reduced the digestibility of DM (3\%) and OM (2.8\%) in animals fed on both HS and LS WSB diets. This was probably due to a decrease in the number of rumen protozoa and bacteria, including several populations of fibrolytic bacteria, and decreased activity of fiber-degrading enzymes (Huws et al., 2010; Patra, 2013). Fibrolytic bacteria are among those most sensitive to inhibition by dietary lipid (Nagaraja et al., 1997).

The higher aNDF content of LS diets, with or without soybean addition, increased the apparent digestibility of EE and aNDF during the present study. In addition to the fact that LS diets contained lower non-fiber carbohydrate contents, this may have been due to a lower degradability of aNDF from the soybean hulls serving to increase the retention time of the digesta in the reticulo-rumen and decrease the rate of passage through the gastrointestinal tract (Oliveira et al., 2007). Also the presence the polyunsaturated fatty acids have been shown to have a toxic effect on some rumen bacteria species, especially cellulolytic bacteria (Maia et al., 2007; Mao et al., 2010). Therefore, the lower rumen digestion of aNDF in WSB in comparison to NSB can be explained by a decline in cellulolytic bacteria number notwithstanding the decrease in their fibrolytic activity.

The effects of lack of dietary starch and soybean on the average daily gain, carcass yield, CG, LEA, and BFT during this study may have been related to the nutritive value of the soybean hulls, which was similar to that of the corn. Possible alterations in rumen fermentation, associated with the different carbohydrate sources, did not affect the efficiency of use of the feeds during growth of the different animal tissues. Effects of soybean hulls on animal performance may be related to the inclusion rate of this feed ingredient. Performance is not compromised at low inclusion rates, as the hulls are more digestible than corn. Thus, when included at low percentage in the concentrate, soybean hulls can reduce metabolic disorders, thereby increasing the availability of energy from other

Table 5

Effect of diets containing high and low starch, with or without soybean (soy ground or no soy ground) on enteric $\mathrm{CH}_{4}$ emission of Nellore bulls finished in feedlot.

\begin{tabular}{|c|c|c|c|c|c|c|c|c|}
\hline & \multicolumn{2}{|c|}{ Soybean } & \multicolumn{2}{|l|}{ Starch } & \multirow[b]{2}{*}{ SEM } & \multicolumn{3}{|c|}{$P$-value } \\
\hline & With & No & High & Low & & $\mathrm{SB}^{1}$ & $\mathrm{~S}^{2}$ & $\mathrm{SB} \times \mathrm{S}$ \\
\hline$g / d$ & $119^{\mathrm{b}}$ & $164^{\mathrm{a}}$ & 141 & 142 & 19.3 & 0.01 & 0.84 & 0.93 \\
\hline $\mathrm{kg} / \mathrm{yr}$ & 43.4 & 60.0 & 51.4 & 51.9 & 14.2 & 0.01 & 0.84 & 0.93 \\
\hline $\mathrm{g} / \mathrm{kg} \mathrm{ADG}^{4}$ & $87.5^{\mathrm{b}}$ & $120^{\mathrm{a}}$ & 102 & 105 & 15.9 & 0.01 & 0.54 & 0.43 \\
\hline $\mathrm{g} / \mathrm{kg} \mathrm{CG}^{5}$ & $121^{\mathrm{b}}$ & $153^{\mathrm{a}}$ & 131 & 142 & 18.9 & 0.01 & 0.13 & 0.42 \\
\hline $\mathrm{g} / \mathrm{kg} \mathrm{DMI}^{6}$ & $14.5^{\mathrm{b}}$ & $17.3^{\mathrm{a}}$ & 15.3 & 16.6 & 2.69 & 0.01 & 0.21 & 0.62 \\
\hline $\mathrm{g} / \mathrm{kg} \mathrm{OMD}^{7}$ & $21.4^{\mathrm{b}}$ & $25.1^{\mathrm{a}}$ & 22.7 & 24.2 & 4.86 & 0.02 & 0.19 & 0.58 \\
\hline $\mathrm{g} / \mathrm{kg} \mathrm{aNDFI}^{8}$ & $48.9^{b}$ & $57.0^{\mathrm{a}}$ & $58.6^{\mathrm{a}}$ & $47.3^{b}$ & 9.61 & 0.03 & 0.10 & 0.11 \\
\hline$\%$ of $\mathrm{GEI}^{9}$ & $3.49^{\mathrm{b}}$ & $4.52^{\mathrm{a}}$ & 3.76 & 4.25 & 0.77 & 0.01 & 0.10 & 0.79 \\
\hline
\end{tabular}

${ }^{1} \mathrm{SB}=$ Soybean; ${ }^{2} \mathrm{~S}=$ Starch; ${ }^{4} \mathrm{ADG}=$ average daily gain; ${ }^{5} \mathrm{CG}=$ carcass gain; ${ }^{6} \mathrm{DMI}=$ dry matter intake; ${ }^{7} \mathrm{OMD}=$ organic matter digestible; ${ }^{8} \mathrm{aNDFI}=\mathrm{NDF}$ intake;

${ }^{9} \mathrm{GEI}=$ gross energy intake.

${ }^{\mathrm{a}-\mathrm{bb}}$ Homogeneous subsets within rows as determined by Tukey HSD at the $5 \%$ level. 
dietary components (Neto et al., 2015).

Enteric $\mathrm{CH}_{4}$ emission expressed as $\mathrm{g} \mathrm{CH}_{4}$ /d was reduced by $28 \%$ in animals fed upon WSB diets, independent of the starch level. It represented an energy profit, i.e., these animals consumed less and gained the same weight as others. It was probably due to retention of energy that was not wasted as $\mathrm{CH}_{4}$, and was reflected in the increase in feed efficiency (0.17). The first explanation of the $\mathrm{CH}_{4}$ mitigating effect of fatty acids is that, regardless of their nature, fatty acids decrease the amount of organic matter fermented in the rumen if they replace a proportion of dietary carbohydrates (Martin et al., 2016). In fact, this was evident in our study because the diets with soybean decreased dry matter intake and consequently, decreased the amount of organic matter fermentable in the rumen. $\mathrm{CH}_{4}$ is produced in ruminants as a by-product of OM fermentation in the rumen and hindgut; this $\mathrm{CH}_{4}$ is an energy loss to the animal and will vary with feed composition and intake (Alstrup et al., 2015).

Lipid supplementation reduces the fermentable substrate and can decrease organic matter and fiber degradability (Knapp et al., 2014). As a consequence, the amount of hydrogen produced during fermentation is reduced, resulting in decreased $\mathrm{CH}_{4}$ production. Besides, supplementation with lipid may reduce the activity of ruminal methanogens and protozoal numbers (Hristov et al., 2013). An increased degree of fatty acid unsaturation will increase the negative effect on fibrolytic bacteria and methanogens (GigerReverdin et al., 2003). Free fatty acids, with their surfactant properties, can disrupt membrane integrity, impair nutrient uptake, and inhibit membrane enzyme activity and energy production, leading to cell death (Desbois and Smith, 2010). Gram-positive bacteria have been reported to be more susceptible to free fatty acids than Gram-negative bacteria (Desbois and Smith, 2010). In addition to the outer cell membrane and cell wall, other cell envelope structures, such as the glycocalyx, may affect the susceptibility of a microbe to free fatty acids. The dietary environment might also affect the toxicity of a free fatty acid to different groups of microbes. However, according to Morgavi et al. (2010), the number of methanogens is not the key factor affecting $\mathrm{CH}_{4} \mathrm{emission}$ A modulation of the activity and diversity of methanogens might be responsible for the $\mathrm{CH}_{4}$-mitigating effect of fatty acids.

Another explanation for decreased $\mathrm{CH}_{4}$ emission is that protozoa act as physical hosts for methanogens and during fermentation produce a high quantity of $\mathrm{H}_{2}$, which is used by the methanogens to reduce $\mathrm{CO}_{2}$ to $\mathrm{CH}_{4}$ (Morgavi et al., 2010). The toxic effect of its fatty acids on protozoa, associated with lower $\mathrm{H}_{2}$ availability to methanogens, appears to be involved in the mitigation of $\mathrm{CH}_{4}$ in ruminants by soybean. Addition of soybean or soybean oil to cattle diets has been shown to reduce rumen protozoa populations by up to $80 \%$ (Fiorentini et al., 2013). Removal of protozoa (defaunation) from the rumen is often associated with increased supply of microbial protein and improved animal productivity (Patra and Saxena, 2009). Therefore, manipulating the $\mathrm{H}_{2}$ in the rumen is key to controlling $\mathrm{CH}_{4}$ emission, and consequently, the metabolic pathways involved in the formation and utilization of $\mathrm{H}_{2}$, and the

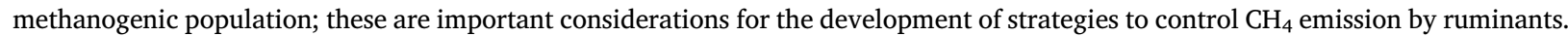

In the present study, the average enteric $\mathrm{CH}_{4}$ emission across all treatments was $51.6 \mathrm{~kg} \mathrm{CH}_{4} / \mathrm{y}$ and, specifically for WSB treatments as the lipid source, $43.4 \mathrm{~kg} \mathrm{CH}_{4} / \mathrm{y}$. These values were lower than the $61 \mathrm{~kg} \mathrm{CH}_{4} / \mathrm{y}$ estimated by the IPCC (2006) for male cattle in Latin America. Though studies have demonstrated that dietary composition affects ruminant GHG production, the IPCC, which is responsible for the development of methodologies to estimate global emission stocks, only distinguishes between diets with more than $900 \mathrm{~g} / \mathrm{kg}$ concentrate and diets with less than $900 \mathrm{~g} / \mathrm{kg}$ concentrate. Energy lost as $\mathrm{CH}_{4}$ emissions (expressed as a percentage of energy intake) was 3.49 and $4.52 \%$ in animals fed WSB and NSB, respectively. These values are lower than those reported by the Intergovernmental Panel on Climate Change (IPCC, 2006) for animals consuming diets with less than $900 \mathrm{~g} / \mathrm{kg}$ concentrate (6.5\% of the GE intake). According to Martin et al. (2007), $\mathrm{CH}_{4}$ losses appear to be relatively constant for diets containing $300-400 \mathrm{~g} / \mathrm{kg}$ concentrate (6-7\% of GE intake), rapidly declining for diets containing $800-900 \mathrm{~g} / \mathrm{kg}$ concentrate (2-3\% of GE intake).

Brazilian livestock has been criticized for emitting significant amounts of GHGs. Possibly, the difference between these values is due to the fact that the methodologies used to estimate the emission of GHGs do not fully correspond to the national reality. In some cases, the methodology used by IPCC (2006) overestimate the emission of GHGs in cattle. It occurs because the numbers of IPCC (2006) are absolute, and it does not take into account the characteristics of each country. The IPCC (2006) itself suggests that regional studies should be performed on this issue. Such criticism has been based on the low zootechnical indices reported in animal husbandry systems, based on degraded pastures or that are below their production potential. An inefficiency of this exploration model has generated higher GHG results per kilogram of meat and/or milk produced.

Tools are being tested (e.g., lipid use, pasture management) to manipulate the rumen and to create management techniques that can reduce $\mathrm{CH}_{4}$ emission, and, consequently, lower energy losses. For example, Carvalho et al. (2016, Neto et al. (2015 and Fiorentini et al. (2014 found lower values of energy losses when compared to those cited by IPCC (2006). Therefore, we realized that the better the quality of the diet, lower is the $\mathrm{CH}_{4}$ emission in comparison to the IPCC default. It should be borne in mind that these tools must be linked to the economic sustainability of the producer. In the future, producers who get committed to environmental sustainability and use mitigation strategies may be rewarded with carbon credits.

Research shows that intensifying the production systems can reduce the enteric emission of $\mathrm{CH}_{4}$, even though the emission of $\mathrm{N}_{2} \mathrm{O}$ can be increased by the use of nitrogen fertilizers, either for grain cultivation or for pasture fertilization. This reduction of GHG per unit of product is mainly related to better utilization of the food and reduction of the age at slaughter. The overall estimation of gas balance is quite complex and requires a lot of research, including more efficient production systems such as silvopastoral and agrosilvopastoral systems that seek a better use of the gases emitted by the activities.

Knowledge of the mechanisms of $\mathrm{CH}_{4}$ synthesis and the factors affecting $\mathrm{CH}_{4}$ production is important. A major challenge for the ruminant production industry is to develop diets and management strategies that minimize relative $\mathrm{CH}_{4}$ production, providing greater production efficiency, and a reduction in the contribution of livestock to global warming. The results of the present study, whereby a roughage:concentrate ratio of $400: 600 \mathrm{~g} / \mathrm{kg}$ was employed, and an average 4\% GE loss as $\mathrm{CH}_{4}$ emission was observed for animals fed diets including soybean, corn, or soybean hulls with corn silage, may be important for future IPCC estimates of global 
emission inventories. Thus, diet modification appears to be a promising method by which the cattle industry can reduce its contribution to GHG emissions.

\section{Conclusion}

The inclusion of approximately $250 \mathrm{~g}$ of soybean $/ \mathrm{kg}$ DM in the diet of feedlot young Nellore bulls results in an increase in feed efficiency and reduces enteric $\mathrm{CH}_{4}$ emission, regardless of the level of starch in the concentrate, without affecting carcass characteristics.

\section{Conflict of interest}

The authors declare no conflict of interest.

\section{Acknowledgment}

The authors thank the São Paulo Research Foundation (FAPESP, grants \#2011/00060-8; \#2013/02418-2; \#2014/09033-1; \#2016/08585-6) for providing financial support.

\section{References}

Association of Official Analytical Chemists, 1990. Official Methods of Analysis, 15th ed. AOAC, Arlington, VA.

Allen, M.S., 2000. Effects of diet on short-term regulation of feed intake by lactating dairy cattle. J. Dairy Sci. 83, $1598-1624$.

Alstrup, L., Frydendahl Hellwing, A.L., Lund, P., Weisbjerg, M.R., 2015. Effect of fat supplementation and stage of lactation on methane production in dairy cows. Anim. Feed Sci. Technol. 207, 10-19.

Bach, A., Yoon, I.K., Stern, M.D., Jung, H.G., Chester-Jones, H., 1999. Effects of type of carbohydrate supplementation to lush pasture on microbial fermentation in continuous culture. J. Dairy Sci. 82, 153-160.

Barletta, R.V., Rennó, F.P., Gandra, J.R., Freitas Júnior, J.E., Verdurico, L.C., Mingoti, R.D., Vilela, F.G., 2012. Blood parameters and performance of dairy cows fed with whole raw soybean. Arch. Zootec. 61, 483-492.

Bassi, M.S., Ladeira, M.M., Chizzotti, M.L., Chizzotti, F.H.M., Oliveira, D.M., Machado, O.R.N., Carvalho, J.R.R., Nogueira, A.A.N., 2012. Oilseeds in zebu cattle diet: intake, digestibility and performance. R. Bras. Zootec. 41, 353-359.

Carvalho, I.P.C., Fiorentini, G., Berndt, A., Castagnino, P.S., Messana, J.D., Frighetto, R.T.S., Reis, R.A., Berchielli, T.T., 2016. Performance and methane emissions of Nellore steers grazing tropical pasture supplemented with lipid sources. R. Bras. Zootec. 45, 730-739.

Casali, A.O., Detmann, E., Valadares-Filho, S.C., Pereira, J.C., Henrique, L.T., Freitas, S.G., Paulino, M.F., 2008. Influence of incubation time and particles size on indigestible compounds contents in cattle feeds and feces obtained by in situ procedures. R. Bras. Zootec. 37, 335-342.

Cochran, R.C., Adams, D.C., Wallace, J.D., Galyean, M.L., 1986. Predicting digestibility of different diets with internal markers: evaluation of four potential markers. J. Anim. Sci. 63, 1476-1483.

Desbois, A.P., Smith, V.J., 2010. Antibacterial free fatty acids: activities, mechanisms of action and biotechnological potential. Appl. Microbiol. Biotechnol. 85, 1629-1642.

Drouillard, J.S., 2012. Utilization of crude glycerin in beef cattle. In: Makkar, H.P.S. (Ed.), Biofuel Co-products as Livestock Feed - Opportunities and Challenges. Food and agriculture organization of the United Nation, Roma, pp. 155-161.

Ferraretto, L.F., Shaver, R.D., 2012. Meta-analysis Impact of corn silage harvest practices on intake, digestion and milk production by dairy cows. Prof. Anim. Sci. 28, 141-149.

Fiorentini, G., Messana, J.D., Dian, P.H.M., Reis, R.A., Canesin, R.C., Pires, A.V., Berchielli, T.T., 2013. Digestibility, fermentation and rumen microbiota of crossbred heifers fed diets with different soybean oil availabilities in the rumen. Anim. Feed Sci. Technol. 181, $26-34$.

Fiorentini, G., Carvalho, I.P.C., Messana, J.D., Castagnino, P.S., Berndt, A., Canesin, R.C., Frighetto, R.T.S., Berchielli, T.T., 2014. Effect of lipid sources with different fatty acid profiles on the intake, performance, and methane emissions of feedlot Nellore steers. J. Anim. Sci. 92, 1613-1620.

Firkins, J.L., 1997. Effects of feeding nonforage fiber sources on site of fiber digestion. J. Dairy Sci. 80, 1426-1437.

Giger-Reverdin, S., Morand-Fehr, P., Tran, G., 2003. Literature survey on the influence of dietary fat composition on methane production in dairy cattle. Livest. Prod. Sci. 82, 71-79.

Hristov, A.N., Oh, J., Firkins, J.L., Dijkstra, J., Kebreab, E., Waghorn, G., Makkar, H.P.S., Adesogan, A.T., Yang, W., Lee, C., Gerber, P.J., Henderson, B., Tricarico, J.M., 2013. Special topics-mitigation of methane and nitrous oxide emissions from animal operations: I. A review of enteric methane mitigation options. J. Anim. Sci. 91, 5045-5069.

Huws, S.A., Lee, M.R., Muetzel, S.M., Scott, M.B., Wallace, R.J., Scollan, N.D., 2010. Forage type and fish oil cause shifts in rumen bacterial diversity. FEMS Microbiol. Ecol. 73, 396-407.

IPCC, 2006. IPCC Guidelines for national greenhouse gas inventories. In: Eggleston, H.S., Buendia, L., Miwa, K., Ngara, T., Tanabe, K. (Eds.), Agriculture, Forestry and Other Land Use, vol. 4 IGES, Hayama, Japan (Prepared by the National Greenhouse Gas Inventories Programme IGES).

Johnson, K.A., Johnson, D.E., 1994. Measurement of methane emissions from ruminant livestock using a SF6 tracer technique. Environ. Sci. Technol. 28, 359-362.

Johnson, K.A., Johnson, D.E., 1995. Methane emissions from cattle. J. Anim. Sci. 73, 2483-2492.

Knapp, J.R., Laur, G.L., Vadas, P.A., Weiss, W.P., Tricarico, J.M., 2014. Enteric methane in dairy cattle production: quantifying the opportunities and impact of reducing emissions. J. Dairy Sci. 97, 3231-3261.

Knudsen, K.E.B., Eggum, B.O., Jacobsen, I., 1987. Nutritive-value of Danish-grown barley varieties, II: Effect of carbohydrate-composition on digestibility of energy and protein. J. Cereal Sci. 6, 187-195.

Kung Jr., L., Grieve, D.B., Thomas, J.W., Huber, J.T., 1984. Added ammonia or microbial inoculant for fermentation and nitrogenous compounds of alfalfa ensiled at various percents of dry matter. J. Dairy Sci. 67, 299-306.

Maia, M.R.G., Chaudhary, L.C., Figueres, L., Wallace, R.J., 2007. Metabolism of polyunsaturated fatty acids and their toxicity to the microflora of the rumen. Antonie van Leeuwenhoek 91, 303-314.

Mao, H.L., Wang, J.K., Zhou, Y.Y., Liu, J.X., 2010. Effects of addition of tea saponins and soybean oil on methane production: fermentation and microbial population in the rumen of growing lambs. Livest. Sci. 129, 56-62.

Martin, C., Dubroeucq, H., Micol, D., Agabriel, J., Doreau, M., 2007. Methane output from beef cattle fed different high-concentrate diets. In: Proceedings of the British Society of Animal Science. Southport : BSAS. p. 46.

Martin, C., Morgavi, D.P., Doreau, M., 2010. Methane mitigation in ruminants: from microbe to the farm scale. Animal 4, $351-365$.

Martin, C., Ferlay, A., Mosoni, P., Rochette, Y., Chilliard, Y., Doreau, M., 2016. Increasing linseed supply in dairy cow diets based on hay or corn silage: effect on enteric methane emission, rumen microbial fermentation, and digestion. J. Dairy Sci. 99, 3445-3456. 
Morgavi, D.P., Forano, E., Martin, C., Newbold, C.J., 2010. Microbial ecosystem and methanogenesis in ruminants. Animal 4, $1024-1036$.

Moss, A.R., Jouany, J.P., Newbold, J., 2000. Methane production by ruminants: its contribution to global warming. Annales de Zootechnie, vol. 49. Institut national de la recherche agronomique, Paris, pp. 231-254.

Nagaraja, T.G., Newbold, C.J., Van Nevel, C.J., Demeyer, D.I., 1997. In: Hobson, P.N., Stewart, C.S. (Eds.), Manipulation of Ruminal Fermentation. The Rumen Microbial Ecosystem. Blackie Academic \& Professional, London, pp. 523-632.

Neto, A.J., Messana, J.D., Ribeiro, A.F., Vito, E.S., Rossi, L.G., Berchielli, T.T., 2015. Effect of starch-based supplementation level combined with oil on intake, performance, and methane emissions of growing Nellore bulls on pasture. J. Anim. Sci. 93, 2275-2284.

Obici, S.Z., Feng, H., Morgan, K., Stein, D., Karkanias, G., Rosseti, L., 2002. Central administration of oleic acid inhibits glucose production and food intake. Diabetes $51,271-275$.

Oliveira, A.S., Campos, J.M.S., Valadares-Filho, S.C., Assis, A.J., Teixeira, R.M.A., Valadares, R.F.D., Pina, D.S., Oliveira, G.S., 2007. Replacing corn with coffee hulls or soyhulls in dairy cows diets: intake, nutrient digestibility, and milk production and composition. Rev. Bras. Zootec. 36, 1172-1182.

Palmquist, D.L., Jenkins, T.C., 1980. Review: fat in lactation rations. J. Dairy Sci. 63, 1-14.

Parsons, G.L., Shelor, M.K., Drouillard, J.S., 2009. Performance and carcass traits of finishing heifers fed crude glycerin. J. Anim. Sci. 87, 653-657.

Patra, A.K., Saxena, J., 2009. The effect and mode of action of saponins on microbial populations and fermentation in the rumen and ruminant production. Nutr. Res. Rev. 22, 204-219.

Patra, A.K., 2013. The effect of dietary fats on methane emissions, and its other effects on digestibility, rumen fermentation and lactation performance in cattle: a metaanalysis. Livest. Sci. 155, 244-254.

Sniffen, C.J., Connor, J.D., Van Soest, P.J., Fox, D.G., Russel, J.B., 1992. A net carbohydrate and protein system for evaluating cattle diets: II: Carbohydrate and protein availability. J. Anim. Sci. 70, 3562-3577.

Sullivan, H.M., Bernard, J.K., Amos, H.E., Jenkins, T.C., 2004. Performance of lactating dairy cows fed whole cottonseed with elevated concentrations of free fatty acids in the oil. J. Dairy Sci. 87, 665-671.

USDA (United States Department of Agriculture), 2014. World Agricultural Production. . http://apps.fas.usda.gov/psdonline/circulars/production.pdf (Accessed 26.01.14).

Valadares Filho, S.C., Marcondes, M.I., Chizzotti, M.L., Paulino, P.V.R., 2010. Nutritional Requirements of Pure and Crossbred Zebu Cattle, 2nd ed. Suprema Gráfica Ltda, Viçosa On-line acess: < http://www.brcorte.com.br > .

Van Soest, P.J., Robertson, J.B., Lewis, B.A., 1991. Methods for dietary fiber, neutral detergent fiber, and nonstarch polysaccharides in relation to animal nutrition. J. Dairy Sci. 74, 3583-3597.

Van Soest, P.J., 1994. Nutritional Ecology of the Ruminants, 2nd ed. Cornell University, Ithaca p. 476.

Veysset, P., Lherm, M., Bébin, D., 2010. Energy consumption, greenhouse gas emissions and economic performance assessments in French Charolais suckler cattle farms: model-based analysis and forecasts. Agric. Syst. 103, 41-50.

Westberg, H.H., Johnson, K.A., Cossalman, M.W., Michael, J.J., 1998. A SF6 tracer technique: methane measurement from ruminants. USEPA - Evaluating Ruminant Livestock Efficiency Projects and Programs. Washington State University, Pullman, Washington p. 40. 